\title{
IMPLEMENTASI LESSON STUDY PADA PROSES PEMBELAJARAN KAJIAN PROSA FIKSI MAHASISWA SEMESTER III STKIP MUHAMMADIYAH KOTABUMI TAHUN AKADEMIK 2017/2018
}

\author{
Sri Widayati *)
}

\begin{abstract}
Abstracs
Implementation of Lesson Study in the third semester students of Indonesian Language and Literature Study Program STKIP Muhammadiyah Kotabumi academic year 2017/2018. The aims of this article is to improve the process of studying of fiction Prose. The undertaken activities are the activities of the Lesson Study team which are consisted of model lecturers and observers (observers). The lesson Study activities are conducted three times open class. Each open class consists of four stages of activity, namely: planning (plan), implementation (do), observation and reflection (see). Each planning stage produces a learning plan, an MFI, and an assessment instrument. The learning process was done through the application of cooperative learning strategies "cooperative learning model typed". The results obtained from the implementation of lesson study, namely increasing the liveliness, creativity, and student independence. Students' understanding of the subject matter of fiction prose fiction was increased. The quality of learning also was increased.
\end{abstract}

Keywords: LSLC, STKIP, studying of fiction prose

\section{PENDAHULUAN}

Mata kuliah Kajian Prosa Fiksi adalah salah satu mata kuliah yang diberikan di semester III Program Studi Pendidikan Bahasa dan Sastra Indonesia pada Sekolah Tinggi Keguruan dan Ilmu Pendidkan (STKIP) Muhammadiyah Kotabumi. Mata kuliah tersebut merupakan mata kuliah yang wajib ditempuh oleh mahasiswa. Selama ini proses pembelajaran yang dilakukan oleh penulis selaku pengampu mata kuliah tersebut, yaitu dengan metode ceramah dan proses pembelajaran masih berpusat pada dosen sehingga mahasiswa cenderung ber sikap pasif saat pembelajaran berlangsung. Oleh karena itu, penulis selaku seorang dosen berusaha meningkatkan kemampuan profesional. Salah satunya dengan cara melakukan pengkajian terha- dap proses pembelajaran.

Berkaitan dengan hal di atas, pada tahun 2017 STKIP Muhammadiyah Kotabumi menerima hibah Lesson Study for Learning Community (LSLC). Hibah tersebut merupakan keberuntungan dan kesempatan bagi penulis dan juga dosen STKIP Muhammadiyah Kotabumi untuk memperbaiki serta meningkatkan kompetensi di bidang pembelajaran. Hibah tersebut salah satunya akan digunakan untuk 
meningkatkan pembelajaran mata kuliah Kajian Prosa Fiksi pada Program Studi Pendidikan Bahasa dan Sastra Indonesia.

Lesson study dikatakan oleh Rusman (2011:380) sebagai model pembinaan profesi pendidik melalui pengkajian pembelajaran secara kolaboratif dan berkelanjutan berlandaskan prinsip-prinsip kolegalitas dan mutual learning, serta membangun learning community. Widhiartha dkk. (2008:9) menyatakan lesson study merupakan sebuah proses pengembangan kompetensi profesional guru yang dikembangkan secara sistematis dalam sistem pendidikan di Jepang dengan tujuan utama menjadikan proses pembelajaran menjadi lebih baik dan efektif. Dalam kegiatan tersebut para guru/dosen secara bersama-sama merencanakan, mengamati, menganalisis, dan memperbaiki pembelajaran yang dilakukannya. Pada awalnya lesson study memang diperuntukkan bagi guru, tetapi kemudian dosen pun dapat menerapkannya. Dalam arti, dosen seperti halnya guru harus bisa mengembangkan kompetensi professionalnya sebagai pendidik.

Menurut Susilo dkk. (2011:2) di dalam pelaksanaan lesson study, guru/dosen secara kolaboratif melakukan rangkaian pembelajaran. Pertama, mempelajari kurikulum dan merumuskan tujuan pembelajaran. Kedua, merancang pembelajaran untuk mencapai tujuan. Ketiga, melaksanakan dan mengamati suatu research lesson (pembelajaran yang dikaji). Keempat, melakukan refleksi untuk men- diskusikan pembelajaran yang dikaji dan menyempurnakannya. Kelima, merencanakan pembelajaran berikutnya.

Putra dkk. (2010:8) menyatakan lesson study ditopang tiga pilar kegiatan, yakni, plan (perencanaan), do (pelaksanaan) dan see (merefleksikan). Plan bertujuan untuk merancang pembelajaran yang dapat membelajarkan mahasiswa dan berpusat pada mahasiswa. Di dalam plan mahasiswa diharapkan berpartisipasi aktif dalam proses pembelajaran sehingga tujuan pembelajaran dapat tercapai. Di dalam do mahasiswa juga aktif mengikuti proses pembelajaran yang diberikan dosen model. Selanjutnya di dalam see (refleksi) bisa diketahui kekurangan dan kelebihan mahasiswa dalam proses pembelajaran sehingga bisa diberikan pemahaman terhadap mahasiswa yang masih belum sempurna memahami materi pelajaran. Kegiatan see (refleksi) merupakan satu bagian dari proses kolaborasi yang merupakan ciri dari lesson study (Lewis, 2002a).

Dikatakan oleh Lewis \& Hurd, (2011) bahwa ungkapan fakta-fakta di dalam observasi tidak diarahkan untuk menghakimi atau mengkritik dosen, tetapi fokus pada pembelajaran mahasiswa. Melalui diskusi hasil temuan-temuan pada proses pem- 
belajaran yang telah berlangsung, seorang dosen memungkinkan dapat mengetahui secara cermat cara dan tingkah laku mahasiswa dalam pembelajaran (Lewis, 2002).

Lesson Study pada dasarnya merupakan pembelajaran kooperatif. Menurut Rusman (2011:27) karakteristik pembelajar- an kooperatif, yaitu: 1) pembelajaran secara tim, 2) didasarkan pada manajemen kooperatif, 3) kemauan untuk bekerja sama, 4) keterampilan bekerja sama. Untuk mencapai hasil maksimal, ada lima unsur dalam model pembelajaran kooperatif yang harus diterapkan (Nurulhayati dalam Rusman, 2011:204). Unsur-unsur tersebut, yaitu: a. pembelajaran kooperatif adalah saling ketergantungan positif, pertanggungjawaban individual,

b. berdasakan masalah yang diungkapkan dalam kemampuan bersosialisasi, d. tatap muka, e. evaluasi proses kelompok.

Pembelajaran Kajian Prosa Fiksi akan dilaksanakan dengan menggunakan metode cooperative learning strategis (CLS). Lonning (1993:1087) mengemukakan bahwa CLS merupakan strategi yang menawarkan suatu bentuk pembelajaran, yaitu belajar kelompok yang dapat menciptakan empat kondisi yang harus dipenuhi untuk membangkitkan perubahan konseptual mahasiswa berdasarkan konstruktivisme. Langkah-langkah pembelajaran CLS, yaitu: a. orientasi (pengenalan topik yang akan dipelajari, b. pemunculan gagasan (mahasiswa diberi kesempatan untuk menyatakan secara eksplisit gagasannya kepada teman, dosen, atau diri sendiri), c. penyusunan ulang gagaan (memberi kesempatan kepada mahasiswa untuk saling bertukar pikiran dengan teman sebaya dan membentuk serta menilai ide yang baru diperoleh pada saat bertukar pikiran), d. aplikasi (memberi kesempatan kepada mahasiswa untuk menerapkan konsep baru yang telah dibentuk ke dalam konteks yang baru dan sudah dikenal).

Dalam metode CLS, mahasiswa dikelompokkan ke dalam beberapa kelompok kecil 4-5 orang. Dosen berusaha memunculkan gagasan mahasiswa lembar kerja mahasiswa (LKM) berupa beberapa butir soal. Mahasiswa diminta untuk menyatakan secara eksplisit gagasannya kepada teman dalam kelompoknya, kepada dosen, dan terutama kepada diri mereka sendiri.

Pembelajaran lesson study diharapkan dapat meningkatkan kreativitas dan hasil belajar mahasiswa. Dengan kerja sama beberapa orang dosen maka pembelajaran dapat langsung dievaluasi setelah dilaksanakan di kelas. Hasil evaluasi diarahkan untuk langkah perbaikan dalam pembelajaran berikunya. 


\section{METODE}

Lesson Study for Learning Community (LSLC) dilaksanakan pada bulan Oktober 2017, semester ganjil tahun akademik 2017/2018. Open lesson dilaksanakan di ruang kelas Prodi Pendidikan Bahasa dan Sastra Indonesia.Sekolah Tinggi Keguruan dan Ilmu Pendidikan (STKIP) Muhammadiyah Kotabumi. Kelas sasarannya, yaitu mahasiswa semester III Program Pendidik- an Bahasa dan Sastra Indonesia. Jumlah mahasiswa seluruhnya 24 orang, yang terdiri dari laki-laki 8 orang dan perempuan 16 orang. Kelompok diskusi yang terbentuk sebanyak lima (5) kelompok dengan masingmasing kelompok berjumlah 4-5 orang mahasiswa.

LSLC dilakukan pada mata kuliah Kajian Prosa Fiksi. Pelaksanaan LSLC dila kukan dengan pendekatan lesson study. Artinya, pembelajaran Kajian Prosa Fiksi dilaksanakan secara kolaboratif dan kolegatif yang melibatkan dosen model, mahasiswa, dan partisipasi dosen sebagai observer. Jumlah siklus yang dilakukan sebanyak 3 siklus. Dalam setiap open lesson terdiri dari 3 tahapan, yaitu: plan (perencanaan), do (pelaksanaan), dan see (review atau refleksi).

\section{a. Tahap Perencanaan(Plan)}

Tahap ini meliputi pengembangan Rencana Pembelajaran yang dilengkapi dengan Lembar Kegiatan Mahasiswa (LKM), bahan ajar, media pembelajaran, skenario pembelajaran, alat evaluasi, dan penyusunan jadwal. Tahap ini dilakukan bersama oleh dosen tim.

\section{b. Tahap Pelaksanaan $(D o)$}

Kegiatan pada tahap ini adalah open lesson di kelas untuk menerapkan hasil dari kegiatan plan. Salah satu anggota dari tim berperan sebagai dosen model dan anggota lainnya berperan sebagai observer/pengamat. Fokus pengamatan diarahkan pada kegiatan belajar mahasiswa, dengan berpedoman pada instrumen yang telah disepakati pada tahap perencanaan (plan), bukan pada penampilan dosen model yang sedang mengajar. Pelaksanaan open lesson 1-3, dosen menerapkan model pembelajaran Cooperatif Learning Strategis (CLS).

\section{c. Tahap Refleksi (See)}

Tahap ini dimaksudkan untuk menemukan kelebihan dan kekurangan pelaksanaan pembelajaran serta untuk menilai apakah tindakan yang dijalankan sudah sesuai rencana, di mana letak kekurangannya dan bagaimana memperbaikinya atau tindakan alternatif lain seperti apa yang dapat dilakukan untuk memperbaiki kekurangan yang ada. Tahap ini diawali oleh dosen model menyampaikan kesan dan pemikirannya mengenai pelaksanaan pembelajaran, selanjutnya diberikan kepada observer yang bertugas sebagai pengamat. Kritik dan saran disampaikan secara bijak tanpa merendahkan atau menyinggung perasaan dosen model 
dengan tujuan untuk memperbaiki praktik pembelajaran ke depan.

\section{HASIL DAN PEMBAHASAN}

\section{SIKLUS 1}

\section{Tahap Perencanaan (Plan)}

Lesson study yang dilaksanakan di STKIP Muhammadiyah Kotabumi terdiri atas plan, do, dan see. Ketiga tahap tersebut dilaksanakan sebanyak 3 kali pertemuan, yaitu pada tanggal 2, 9, dan 16 Oktober 2017. Pertemuan pertama dilaksanakan tanggal 2 Oktober. Pada tahap plan, tim membahas mengenai permasalahan pembel- ajaran Kajian Prosa Fiksi sekaligus review atas pengalaman pembelajaran yang biasa dilakukan. Dosen merumuskan fokus pembelajaran dengan merancang rencana pembelajaran berbasis lesson study mulai dari merancang lesson design sampai merancang chapter design. Materi yang akan disampaikan untuk mata kuliah Kajian Prosa Fiksi, yaitu materi hakikat prosa fiksi serta perbedaan prosa fiksi dan prosa nonfiksi.

Kegiatan lain yang dikerjakan pada tahapan plan, yaitu mempersiapkan silabus dan satuan acara perkuliahan, membuat lembar kerja mahasiswa, membuat bahan ajar, membuat media pembelajaran berupa slide power point, dan membuat lembar observasi. Pertemuan kedua pada tahap plan juga dibahas mengenai teknis tahapan do untuk open lesson (buka kelas). Pertemuan ketiga memeriksa segala kesiapan untuk pelaksanaan open lesson dan mempersiapkan segala peralatan yang dibutuhkan.

\section{Tahap Pelaksanaan (Do)}

Tahapan do atau pelaksanaan open lesson siklus 1 dilaksanakan pada tanggal 2 Oktober 2017 seusai plan. Pengaturan ruang kelas dilakukan untuk memberikan posisi yang praktis bagi para observer agar dapat mengamati proses pembelajaran secara utuh. Pembekalan bagi para observer pun telah dilakukan sebelum open lesson untuk menginformasikan batasan dan tugasnya selaku observer. Berikut langkah-langkah pembelajaran yang dilakukan dosen model pada open lesson 1:

a. Pendahuluan (5 menit): dosen model membuka kelas dengan pengucapan salam, dosen model menyapa kelas untuk menanyakan kabar dan kehadiran mahasiswa, melakukan apersepsi dan pemberian motivasi melalui pengajuan pertanyaan dan penayangan gambar pada slide.

b. Kegiatan inti (93 menit): dosen model menginformasikan judul materi pembahasan dan tujuan pembelajaran, menjelaskan materi secara umum dan menerangkan konsep-konsep esensial. Selanjutnya dosen model menginstruksikan bahwa pembelajaran akan dilakukan melalui diskusi kelompok, 
membagi kelompok, membagikan lembar kerja Mahasiswa (LKM) dan bahan ajar. Dosen model menjelaskan proses diskusi dan tugas yang harus dilakukan setiap kelompok diskusi, yaitu memecahkan masalah yang disajikan dalam LKM, Mahasiswa berdiskusi memecahkan masalah atau pertanyaan yang disajikan dalam lembar kerja. Dosen model berkeliling membimbing dan menjadi fasilitator proses diskusi. Dosen model menegaskan bahwa waktu diskusi telah selesai. Dosen model membuka kegiatan presentasi hasil diskusi di depan kelas. Selesai proses diskusi, dosen model memberi apresiasi terhadap kelompok terbaik. Langkah selanjutnya adalah proses penarikan kesimpulan sebagai penguatan materi atas pembelajaran yang dilakukan, dan pelaksanaan evaluasi.

c. Penutup (2 menit): dosen model memberikan penugasan terkait pertemuan selanjutnya.

\section{Tahap Refleksi (See)}

Tahapan see atau refleksi dilaksanakan langsung setelah open lesson berakhir. Kegiatan ini merupakan satu bagian dari proses kolaborasi yang merupakan ciri dari lesson study. Fakta-fakta yang didapat selama observasi, tidak diarahkan untuk menghakimi atau meng- kritik dosen, tetapi fokus pada pembelajaran mahasiswa. Dosen model dan observer bersama untuk mengevaluasi proses pembelajaran. Berikut intisari dan rekomendasi hasil tahapan refleksi (see) siklus 1:

a. Saat awal pembelajaran mahasiswa terlihat tegang dan binggung dengan keberadaan para observer di kelas. Begitu juga dengan kegiatan pembelajaran yang dilakukan dengan pendekatan lesson study.

b. Beberapa mahasiswa tidak terlibat dalam diskusi. Hal ini terjadi karena mahasiswa tidak memahami, malas, dan mengantuk.

c. Kesempatan mencari referensi melalui HP membuat mahasiswa mengunakan HP di luar kegiatn pembelajaran.

d. Saat presentasi kelompok IV di depan kelas, kelompok lain masih sibuk sendiri mengerjakan tugas masing-masing.

e. Interaksi antara mahasiswa kurang maksimal.

f. Masih ada kelompok yang tidak melakukan diskusi.

g. Proses penyimpulan lembar kerja tidak dilakukan secara bersama/berdiskusi.

h. Masih minimnya pengetahuan mahasiswa terkait materi pembelajaran.

i. Secara umum proses pembelajaran telah berlangsung dengan baik.

j. Pembelajaran sudah berpusat pada mahasiswa.

Berdasarkan data hasil pedoman observasi kegiatan do dalam lesson study siklus 1 menunjukkan bahwa proses pembelajaran dengan pendekatan lesson study 
dalam tahapan do dilaksanakan dengan baik oleh dosen model. Selanjutnya im- plementasi lesson study memiliki penga- ruh yang positif terhadap peningkatan motivasi dalam mengembangkan proses pembelajaran. Hal ini terlihat dari respon observer yang menyatakan positif terhadap proses pembelanjaran dengan lesson study.

Hal ini terlihat dari respon observer yang menunjukkan $61 \%$ responden menyatakan setuju dan $35,67 \%$ sangat setuju. Artinya sebesar 96,67\% responden menyatakan positif. Tingginya tingkat penerimaan menunjukkan bahwa implementasi lesson study memberi pengaruh positif dalam meningkatkan kualitas pembelajaran Kajian Prosa Fksi. Mahasiswa juga menunjukkan respon yang positif setelah mengikuti proses pem- belajaran dengan pendekatan lesson study, khususnya setelah mengikuti tahapan do dan see pada siklus 1 .

\section{SIKLUS 2}

Tahapan plan pada siklus 2 dilaksanakan pada tanggal 9 Oktober 2017 yang merupakan konsolidasi dari hasil rekomendasi pada refleksi siklus 1. Tim merumuskan rancangan pembelajaran dengan merefleksi segala kekurangan pada siklus 1 . Materi pembelajaran pada siklus 2 tentang unsur intrinsik karya sastra, yaitu: tema, amanat, dan penokohan

Tahapan do siklus 2 dilaksanakan pada hari yang sama setelah plan, sesuai jadwal mata kuliah Kajian Posa Fiksi. Secara umum langkah-langkah pembelajaran yang digunakan sama dengan siklus 1. Intisari pelaksanaan pembelajaran siklus 2 yang membedakan dengan siklus, yaitu:

a. adanya penekanan dalam apersepsi dan motivasi;

b. saat sesi presentasi tiap ke-lompok berakhir, model selalu melakukan penguatan (reinforecement) atas topik yang dibahas;

c. soal yang digunakan untuk penilaian proses melalui LKM telah dirancang oleh dosen model;

d. dosen menginstruksikan mahasiswa untuk mendiskusikan materi yang berkaitan dengan tema dan penokohan;

e. sebagian besar mahasiswa sudah terlibat dalam diskusi;

f. mahasiswa sudah mencari referensi sebelum perkuliahan dimulai;

g. interaksi antara mahasiswa sudah mulai terbangun;

h. proses penyimpulan lembar kerja sudah dilakukan secara bersama/berdiskusi.

Tahapan see siklus 2 langsung dilaksanakan setelah open class selesai. Dosen model mendapat kesempatan pertama untuk mengungkapkan kesan atau kesulitan dalam melaksanakan kelas terbuka untuk diobservasi oleh kolega. Selanjutnya observer menyampaikan fakta-fakta hasil temuan dalam proses pembelajaran. Dalam siklus 2, 
proses pem- belajaran telah berlangsung dengan baik. Dalam arti bahwa sudah ada perhatian mahasiswa terhadap pembelajaran. Meski- pun sudah ada kemajuan, masih terlihat ada mahasiswa yang tidak bekerja sama dengan kelompok. Mahasiswa juga belum sepenuhnya berkonsentrasi pada materi. Dalam siklus 2 semua langkah pembelajaran telah muncul dan dilaksanakan dengan baik oleh model.

Dari hasil pelaksanaan proses $d o$ dapat dinyatakan bahwa implementasi lesson study memberi pengaruh positif dalam meningkatkan kualitas pembelajaran Kajian Prosa Fiksi. Tingginya tingkat penerimaan tersebut disebabkan oleh persepsi positif akan manfaat lesson study yang mampu meningkatkan kualitas pembelajaran. Mahasiswa pun merespon positif terhadap implementasi lesson study.

Respon observer pada lesson study siklus 2 sebesar $65 \%$ menyatakan setuju dan $34 \%$ menyatakan sangat setuju. Tingginya tingkat penerimaan menunjukkan bahwa implementasi lesson study memberi pengaruh positif dalam meningkatkan kualitas pembelajaran Kajian Prosa Fiksi. Hal lain yang mendorong terjadinya peningkatan kualitas pembelajaran Kajian Prosa Fiksi melalui implementasi lesson study adalahadanya proses kolaboratif yang dilakukan oleh tim. Baik pada tahapan plan, do maupun see.

\section{SIKLUS 3}

Tahapan plan pada siklus 3 dilaksanakan pada tanggal 16 Oktober 2017 yang merupakan konsolidasi dari hasil refleksi siklus 2. Tim merumuskan rancangan pembelajaran dengan merefleksi segala kekurangan pada siklus 2. Materi pembelajaran pada siklus 3 tentang unsur intrinsik karya sastra, yaitu: alur, latar, dan diksi.

Tahapan do siklus 3 dilaksanakan pada hari yang sama setelah plan, sesuai jadwal mata kuliah Kajian Posa Fiksi. Rencana tindakan pada siklus ketiga ini adalah pelaksanaan hasil refleksi yang sudah dilakukan pada akhir kegiatan siklus kedua. Hasil refleksi siklus kedua yang perlu diperbaiki adalah pada saat pelaksanaan pembelajaran, sedangkan perencanaan tidak mengalami banyak perubahan hanya perlu penyempurnaan.

Tahapan see siklus 3 langsung dilaksanakan setelah open class selesai. Dosen model mendapat kesempatan pertama untuk mengungkapkan kesan atau kesulitan dalam melaksanakan kelas terbuka untuk diobservasi oleh kolega. Selanjutnya observer menyampaikan fakta-fakta hasil temuan dalam proses pembelajaran. Intisari hasil refleksi siklus 3, yaitu proses pembelajaran telah berlangsung dengan baik. Mahasiswa begitu antusias dalam mengikuti pem belajaran. Semua langkah pembelajaran telah muncul dan dilaksanakan dengan baik oleh 
model. Mulai dari apersepsi sampai dengan evaluasi dan penugasan.

Pada siklus 3 antusias mahasiswa semakin tampak. Mahasiswa lebih mandiri dalam mengerjakan tugas kelompok. Lebih terlihat aktif dalam diskusi kelas, mahasiswa secara bergantian menjawab pertanyaan dan saling memberi masukan. Interaksi mahasiswa dengan media semakin optimal, mereka semakin serius dalam berdiskusi. Dosen model pun lebih aktif membimbing mahasiswa. Respon observer pada lesson study siklus 3 sebesar 78\% menyatakan setuju dan $20 \%$ menyatakan sangat setuju. Tingginya tingkat penerimaan menunjukkan bahwa implementasi lesson study memberi pengaruh positif dalam meningkatkan kualitas pembelajaran Kajian Prosa Fiksi.

\section{SIMPULAN}

Berdasarkan hasil pelaksanaan lesson study pada mata kuliah Kajian Prosa Fiksi di STKIP Muhammadiyah Kotabumi sudah sesuai dengan prosedur yang ditetapkan dalam pembelajaran lesson study, yaitu plan (perencanaan), do (pelaksanaan) dan see (refleksi). Ketiga tahapan tersebut dapat meningkatkan kreativitas dosen dan memotivasi mahasiswa. Selanjutnya, di dalam kegiatan lesson study, dosen bekerja sama dengan observer untuk memecahkan persoalan pembelajaran dan mencari solusi terhadap masalah yang dihadapi di kelas untuk menciptakan suasana pembelajaran yang menyenangkan pada pertemuan berikutnya.

Pembelajaran Kajian Prosa Fiksi dengan lesson study di STKIPM ternyata mampu memperbaiki praktik pembelajaran di kelas serta dapat meningkatkan kreativitas dan memotivasi mahasiswa dalam belajar. Meningkatnya motivasi mahasiswa dengan pembelajaran lesson study karena pembelajaran difokuskan pada mahasiswa, baik dalam pengamatan belajar, suasana belajar, motivasi belajar maupun dalam pemilihan strategi pembelajaran. Selain itu juga karena adanya perencanaan pembelajaran yang baik, media pembelajaran yang menarik, kerja sama dosen dan pengamatan observer yang menyeluruh. Dengan demkian, dapat dikatakan bahwa implementasi lesson study dalam perkuliahan Kajian Prosa Fiksi mampu meningkatkan kualitas pembelajaran. Hal ini ditandai dengan meningkatnya aktivitas mahasiswa dalam mengikuti pembelajaran Kajian Posa Fiksi serta adanya respon positif terhadap implementasi lesson study.

\section{DAFTAR RUJUKAN}

Lewis, C \& Hurd, J. 2011. Lesson Study Step by Step (How Teacher Learning Communities Improve Instruction). Portsmouth: Online. http://www.heinemann.com/shared/ onlineresources/E00964/ Lewis_Hurd_websample.pdf. Diakses pada tanggal 5 Oktober 2017. 
Lewis, C. 2002. Lesson study: A handbook for Teacher-led Improvement of Instruction (Brief guide to lesson study). Philadelphia: Research for better schools. Online www.lessonresearch.net/briefguide. pdf.

Lonning, R.A. 1993. Effect of Cooperative Learning Strategy on Student Verbal Interactions and Achievment durng Conceptual Change Intruction in $10^{\text {th }}$ Grade General Science. Journal of Research in Science Teaching. 30 (9). $1087-$ 1099

Putra, Yukon dkk, 2010. Belajar dari Pembelajaran: Best Practice Implementasi Lesson Study. Jakarta: Direktorat Tenaga Kependidikan, Dirjen PMPTK Kementerian Pendidikan Nasional.

Rusman. 2011. Model-Model Pembelajaran: Mengembangkan Profesional Guru. Jakarta: Rajawali Press.

Widhiartha, Ashintya Putu dkk. 2008. Lesson Study: Sebuah Upaya Peningkatan Mutu Pendidik Pendidikan Nonformal. Surabaya: Prima Printing Surabaya. 